\title{
Relationship between School Autonomy and Students' Academic Achievement in Government Secondary Schools in East Hararghe Zone, Oromia Regional State, Ethiopia
}

\author{
Shimelis Sahilu1 ${ }^{*}$, Ziyn Engdasew ${ }^{2}$, Garkebo Basha ${ }^{3}$, Feyera Dinsa4 \\ ${ }^{1}$ Department of Educational Planning and Management, College of Education and Behavioral Sciences, PhD Program in \\ Educational Leadership and Policy Studies, Haramaya University, Haramaya, Ethiopia \\ ${ }^{2}$ Department of Educational Planning and Management, College of Education and Behavioral Sciences, Adama Science and \\ Technology University, Adama, Ethiopia \\ ${ }^{3}$ Department of Adult Education and Community Development, College of Education and Behavioral Sciences, Haramaya \\ University, Haramaya, Ethiopia \\ ${ }^{4}$ Department of Educational Planning and Management, College of Education and Behavioral Sciences, Haramaya University, \\ Haramaya, Ethiopia \\ Email: `Shimelis445@gmail.com, engdasewziyn1970@gmail.com, garadured@gmail.com, feyera2009@gmail.com
}

\begin{abstract}
How to cite this paper: Sahilu, S., Engdasew, Z., Basha, G., \& Dinsa, F. (2021). Relationship between School Autonomy and Students' Academic Achievement in Government Secondary Schools in East Hararghe Zone, Oromia Regional State, Ethiopia. Creative Education, 12, 2441-2463. https://doi.org/10.4236/ce.2021.1210183
\end{abstract}

Received: August 31, 2021

Accepted: October 26, 2021

Published: October 29, 2021

Copyright $\odot 2021$ by author(s) and Scientific Research Publishing Inc. This work is licensed under the Creative Commons Attribution International License (CC BY 4.0).

http://creativecommons.org/licenses/by/4.0/ (c) (i) Open Access

\begin{abstract}
In a number of countries, education systems are moving towards practices of school autonomy reform to increase learning outcomes. As a result of this reform, decision-making at the school level has become supreme, and the role of the school leader has gained in significance. The aim of school autonomy is to improve the efficiency of education quality by independence and flexibility in managing existing resources. Regardless of these trends, amazingly little is known about how schools use school autonomy in practice, and there were a lot of controversies regarding the relationship between school autonomy and students' academic achievement. Therefore, the purpose of this study was to find out the practiced areas of school autonomy and to examine the magnitude of relationship between the areas of school autonomy and students' academic achievement in government secondary schools in the study area by using a descriptive-correlational survey research designs with a quantitative approach. A total of 502 respondents (secondary school teachers $n=347$, and zone and district education offices experts $n=155$ ) were samples. The sample schools were selected by stratified random sampling and the respondents were selected by simple random sampling using RAND or RANDBETWEEN function on Microsoft Excel. Closed-ended questionnaires were employed for gathering data from the respondents. The correlation statistical test was used
\end{abstract}


to describe and measure the degree of association (or relationship) between the variables or sets of scores. Moreover, t-test was also conducted to test the difference between the two groups. Analysis results demonstrate that there have been practices of the three areas of school autonomy in the schools, that is, personnel management autonomy, financial management autonomy and academic autonomy. Moreover, school autonomy practices in general and its three dimensions in particular have weak to moderate significant positive relationships with students' academic achievement. The overall conclusion drawn from the results of this study was that granting autonomy to secondary schools may be the best idea for the better performance of educational systems in the study area. Further, similar to many of the developed countries, practice of school autonomy in developing countries was also one of the means to improve students' academic achievement.

\section{Keywords}

Academic Autonomy, Financial Management Autonomy, Personnel Management Autonomy, Relationship, School Autonomy, Secondary Schools and Students' Academic Achievement

\section{Introduction}

A popular educational decentralization strategy in many countries is School Based Management (SBM), defined as the systematic decentralization of authority to the school level including responsibility for decisions on significant matters related to school operations within a framework of centrally determined goals, policies, curricula, standards, and accountability (Caldwell, 2005). Since SBM encompasses diverse practices and policies applied in different forms in many countries in the world, the World Bank has initiated the design of SBM indicators such as school autonomy (SA) in budget planning and approval, personnel management, participation of the school council in school finance, assessment of school and student performance, and school accountability that could be of use to governments to identify and implement practices and policies that increase autonomy and accountability, and by inference, induce the education system to produce better learning outcomes (World Bank, 2007; and Patrinos, 2011).

School autonomy is a fundamental feature of SBM in which schools are delegated with decision-making authority over their operations. School management under autonomy facilitates an important role to the school leaders which embodies the interest of students and enables school finance management, personnel management and academic activities (Di Gropello, 2006; Barrera, Fasih, \& Patrinos, 2009). Eurydice (2007) stated that there were four degrees of SA that schools can enjoy. These were full autonomy, limited autonomy, discretionary delegation and no autonomy. Accordingly, one of the focuses of this study was to identify the level of the SSs degree of autonomy in the study area.

School autonomy is widespread throughout the world as a predominant edu- 
cational reform movement (Organization for Economic Co-operation and Development (OECD), 2014). Global policy makers' view is increasing the autonomy of schools as a means of school and system improvement. Effective school principals' leadership in SA contexts is critical in making essential linkage between system policy and improved Students' Academic Achievement (SAA) (Bloom, Lemos, Sadun, \& Van Reenen, 2015). The success of SA depends on school principals' effective leadership in their schools and communities to implement policy and, this action, pave way of opportunities for school improvement leading to improved SAA (Brauckmann \& Schwarz, 2014).

A key factor affecting school system functioning is its degree of decentralization, which should allow schools to be more autonomous in their decisionmaking and in the planning and use of their human and financial resources (Di Gropello, 2004). By giving more autonomy to schools, local communities can receive education that is more tailored to their needs, which should increase the demand for schooling. By giving schools, more decision-making power local communities can give schools more support and, in turn, hold them more accountable for their teaching-learning performance that leads to SAA (Barrera et al., 2009). Therefore, this is one of the major reasons that initiated the researcher to select this research title.

Improving SAA relies on the smooth functioning of a system comprised of many interconnected factors. It is widely accepted that for education to yield good results, there has to be a proper mix of teacher quality, school curriculum, school environment, home environment, and other factors that motivate students and teachers to apply themselves and increase student knowledge (Vegas \& Petrow, 2008). The interaction among these factors is complex, Umansky (2005), but in order to use education policy effectively it is necessary to understand the internal efficiency of those factors considered pivotal for improving learning. The analysis of the most important factors affecting education is a necessary step to understand how an education system should change in order to improve its outcomes (Arcia, Patrinos, Porta, \& Macdonald, 2011).

Students perform significantly better in schools that have autonomy in process and personnel decisions such as budget allocations, hiring and firing teachers, in addition to the choice of textbooks and methods of instruction (Fuchs \& Woessmann, 2007). Moreover, Naper (2010) showed that autonomy in hiring of teachers heightens school effectiveness. Autonomy in staffing decisions also proves to positively affect students' test scores in mathematics based on the PISA 2003 database (Woessmann, Luedemann, Schutz, \& West, 2009). Likewise, Eskeland and Filmer (2007) report a positive relation of school autonomy in management on educational outcomes in the United Kingdom and Argentina respectively. Similarly, Eurydice (2007) provides evidence of a positive effect of SA on learning in Europe.

On the other hand, autonomy in some areas can lead to negative consequences. Hanushek and Woessmann (2011) as well as Woessmann et al. (2009) argue that SA regarding budget formulation and teacher autonomy regarding subject topics 
to be covered in class have a negative impact on student test scores. In addition, Woessmann (2001) shows that SA in budget formulation has a negative effect on student test scores in both mathematics and science.

A number of studies of SA on SAA have been conducted in a number of countries. A study in Boston found that there was increase in Mathematics results of consecutive years in schools practicing the autonomy (Abdulkadiroglu, Angrist, Dynarski, Kane, \& Pathak, 2011). A study of the Harlem Children's Zone, a program that focuses on the poorest minority students in that neighborhood, found that students in autonomous school system scored better results in Mathematics and English (Dobbie \& Fryer, 2011). In addition to this, World Bank reported that in most developing countries, SBM has produced only modest gains in student learning and it did not correlate with increased learning outcomes (World Bank, 2013).

Moreover, the researcher tried to search for local studies and faced high shortage of related studies. Nevertheless, there are few studies conducted in the Ethiopian context that found the following results. A study by Ethiopian Academy of Sciences indicated that quality of education is deteriorating in schools, and in turn resulted in deterioration of SAA (Ethiopian Academy of Sciences, 2015). This study concluded that one of the important factors that could contribute toward quality education is SA. Other research conducted at national level on SBM and decision-making in Ethiopian government schools found out that the schools constrained the process of devolving decision-making authority to school level, that is, lack of autonomy (Abebe, 2012). In addition to this, in Ethiopia, educational decentralization had not achieved the intended objectives and there is acute implementation of local governance policy, which means SA is at its infant stage in the Secondary Schools (SSs) (Shibeshi, 2009).

Furthermore, as seen from the above literatures, the effectiveness of SA also depends on the country's level of development, where autonomy is more likely to be successful in developed countries than in developing ones. In addition to this, World Bank (2007) reported that, unlike in developed countries where SA is introduced explicitly to improve SAA, how SA will eventually affect SAA in developing countries is less clear. The MoE (2017), the new document of education development road map, also indicated that the extent of decentralization to school is not to the expected level, the most important educational tier where decentralization can make difference seems left behind. Further, the move towards more autonomy with accountability, shifting the locus of control to schools was not materialized.

Accordingly, the purpose of SA continues to be argumentative in many circles, but of the subjects of argument, this study focuses on the relationship between SA and SAA in the context of education in the $21^{\text {st }}$ Century. The focus on SAA is especially timely, because of the Ethiopian Government's interest as part of its School Improvement Program initiative since the formulation of the GEQIP. In addition to this, the directive for school leadership and financial administration explicitly indicated the areas in which the school should be auto- 
nomous, that is, there is initiative of making the SSs autonomous in personnel management, financial management and academic activities (MoE, 1994).

This study is timely because the relationship between SA and SAA has emerged as the most important issue in research, policy and practices on the phenomenon. Moreover, the relationship between SA and SAA was rarely stated explicitly in developing countries like Ethiopia and particularly in the study area.

As can be concluded from the above evidences, there is a need for governments and perhaps international agencies to invest on SA innovations at the school level and to disseminate examples of best practices of SA reforms from around the world. Therefore, these could be the major reasons for the researcher to investigate the relationship between SA and SAA, which in turn showed whether the autonomy is successful or not in the case of the study area.

Therefore, this study was aimed at addressing the following research questions based on the above presented research gaps and arguments.

1) Which areas of SA do the SSs exercise in their leadership practices?

2) What is the magnitude of relationship between SA and SAA?

\section{Research Design and Methodology}

\subsection{Research Design}

In this study, descriptive-correlational survey research designs with quantitative approach were used. Quantitative research depends on the collection and analysis of numerical data to describe, explain variables and phenomena under study (Gay, Mills, \& Airasian, 2009). Moreover, it is used to describe current situations, establish relationship between variables, and sometimes attempts to explain causal relationships between variables. Therefore, descriptive-correlational survey design was used for this study.

\subsection{Source of Data}

The sources of data for this study were teachers and experts of education offices from districts, towns and zone education offices. The data were collected using closed-ended questionnaires.

\subsection{Population of the Study}

East Hararghe Zone, Oromia, Ethiopia, has 57 government SSs and 1 private SS with 58 principals, 2169 teachers, 24 SSs supervisors, and 313 school improvement and teachers development programs experts. However, with this research scope, 347 teachers from the 28 SSs and 155 office experts from the 17 district offices and 1 zone office were respondents of the questionnaires. Therefore, 502 participants were respondents of the questionnaires.

\subsection{Sample Size and Sampling Techniques}

2.4.1. Sample Size and Sampling Techniques of the Secondary Schools Stratified random sampling was used to make the schools more homogeneous, 
and this stratified sampling may results in more reliable and detailed information. Therefore, the schools were divided in to two strata based on the size of their staff and students that is, stratified in to small SSs and large SSs.

After the stratification, the researcher used Yamane (1967) and Cochran (1977) correction formula for determining representative sample size from each stratum. That is, by using simple random sampling $n$ units are selected out of a population of size $N_{1}$ and $N_{2}$ by giving equal probability to all units. Accordingly, to calculate $n_{1}$ from $N_{1}$ using Yamane (1967) formula, $n_{1}=\frac{N_{1}}{1+N_{1} e^{2}}$ where $n_{1}$ is the required sample size from the first stratum, $N_{1}$ is the total population size of the first stratum and $e$ is the desired level of precision, $n_{1}=\frac{27}{1+27 \times 0.05^{2}}=25$ and then, using Cochran (1977) correction formula to calculate the final sample size, $\quad n_{1}=\frac{25}{1+(25-1) / 27}=13$ SS will be selected to be sample SSs from the first stratum. Similarly, to calculate $n_{2}$ from $N_{2}$ using Yamane (1967) formula, $n_{2}=\frac{N_{2}}{1+N_{2} e^{2}}$ where $n_{2}$ is the required sample size from the second stratum, $N_{2}$ is the total population size of the second stratum and $e$ is the desired level of precision, $n_{2}=\frac{30}{1+30 \times 0.05^{2}}$ and then, using Cochran (1977) correction formula to calculate the final sample size, $n_{2}=\frac{28}{1+(28-1) / 30}=15$ SS will be selected to be sample SSs from the second stratum.

As calculated above, from the first stratum 13 SSs were sample and from the second stratum 15 SSs were sample. Therefore, the total sample size of the SSs was 28 SSs. Therefore, the 28 sample SSs were selected using simple random sampling as clearly discussed below.

To select the 28 sample SSs, the RAND or RANDBETWEEN function on Microsoft Excel will be used to assign a random number to each name of schools in each stratum, and to randomly pick the 28 sample SSs using an Index Rank formula retrieved from https://www.ablebits.com was used separately for each stratum (Cheusheva, 2021).

\subsubsection{Sample Size and Sampling Techniques of Teachers Respondents}

To determine the target sample size of teachers from the 28 sample SSs, using simple random sampling technique, the formula of Yamane (1967) is used assuming $95 \%$ confidence level. Thus, out of the 2169 teachers of the 57 government SSs, $n=\frac{2169}{1+2169 \times 0.05^{2}}=338$ teachers are taken as a target sample from the SSs. To represent equal proportions of sample teachers for each SSs the formula $P s=\frac{n}{N} X$ is used, where, $P s=$ Proportional allocation to sample size, $n$ is total teachers' sample size, $N=$ Total number of teachers in the 28 SSs and $X=$ number of teachers in each sample schools. For example, for Adele SS, 
$P s=\frac{338}{1207} \times 50=0.28 \times 50=14$. That is, 14 teachers were used as sample teachers

from Adele SS, and the same procedure was applied for other sample SSs as shown in Table 1 below. Accordingly, 347 teachers were taken as a participant of this study.

To select the 347 sample teachers the RAND or RANDBETWEEN function on Microsoft Excel was used to assign a random number to each name of teachers. First, a name list of all teachers in the schools were collected from each sample SSs and feed in to Excel separately. Then, 347 sample teachers were randomly picked using an Index Rank formula retrieved from https://www.ablebits.com. Therefore, using this randomization method, names of sampled teacher were generated for the 28 sample SSs separately according to the number of sampled teachers shown in Table 1 . The 347 teachers were provided with questionnaires prepared for teachers to gather their responses.

Moreover, the 15 districts, 2 town administrations and zone education offices (total of 18 education offices) of East Hararghe Zone have 253 experts of school improvement program, teachers and school leaders' development program experts. Therefore, the total population of these experts is 253 that was also found to be unmanageable size, and similarly, by using Yamane's formula

$n=\frac{N}{1+N e^{2}}=\frac{253}{1+253 \times 0.05^{2}}=155$ office experts were calculated to be the sample from the respective education offices that were participants of the study. To select the individual participants from each office the approach used was similar to that of teachers, that is, the RAND or RANDBETWEEN function on Microsoft Excel.

To sum up, from the 347 teachers from the 28 sample secondary schools and the 155 education office experts were used as respondent for questionnaires. That is, this study participated $347+155=502$ participants of the study.

\subsection{Instruments of Data Collection}

Modified closed-ended questionnaires were prepared for teachers and experts of education offices. Questionnaire is widely used in educational research to obtain information about certain conditions and practices and to inquire into opinions and attitudes of individuals and groups. Therefore, data for this study were gathered from 347 teachers of the SSs and 155 education office experts, total of 502 respondents, through questionnaires containing closed-ended items. The researcher prepared closed-ended questionnaires using 5-point Likert scale for the

Table 1. Summary of samples of teachers and education office experts.

\begin{tabular}{ccccc}
\hline S. No. & Population Type & Total Population Size & Sample Size & $\begin{array}{c}\text { Percentage of } \\
\text { sample (\%) }\end{array}$ \\
\hline 1. & Secondary school teachers & 1235 & 347 & 28.1 \\
2. & Education office experts & 253 & 155 & 61.2 \\
& Total & 1488 & 502 & 33.7 \\
\hline
\end{tabular}


2 types of respondents (teachers and office experts).

Before distributing the questionnaire to gather actual data, the validity and reliability test of the items were conducted. The validity of the items was tested by the experts in the area, teachers, school principals and supervisors. To test the reliability of the items pilot study was conducted using secondary school teachers $(n=15)$ and education office experts $(n=5)$, who were not included in the samples of the major study. Accordingly, for the purpose of this study, the Cronbach's alpha was applied. The coefficient alpha ranges in values from 0 (no reliability) to 1 (perfect reliability). According to Gregory (2000) cited in Manning and Munro (2006), the values of Cronbach's alpha above 0.70 are considered to represent "acceptable" reliability, above 0.80 "good reliability", and above 0.90 to represent "excellent" reliability. Therefore, in this study the value of Cronbach's alpha was 0.81 , which is in a range of 0.70 to 0.85 , indicating an acceptable and good reliability of the items or questions in the questionnaire.

\subsection{Methods of Data Analysis}

The quantitative data were analyzed using descriptive statistics such as frequency, mean and percentages, and inferential statics analysis used to look for the significant relationship between the variables were Pearson Product Moment Correlation and regression analysis using Statistical Package for Social Sciences (SPSS) version 22.

The correlation statistical test was used to describe and measure the degree of association (or relationship) between the variables or sets of scores. In the case of only two variables, this means that to say two variables share common variance or they co-vary together, product-moment correlation coefficient (r) was used. Moreover, the researcher will use the correlation statistic to see what impact single or multiple independent variable/s have on a dependent variable (outcome), the researcher used regression analysis. In this regression analysis, the variation in the dependent variable was explained by the variance of each independent variable (the relative importance of each predictor), as well as the combined effect of all independent variables (the proportion of criterion variance explained by all predictors), that is determination coefficient designated by $R^{2}$.

\section{Results and Discussions}

\subsection{Demographic Variables and Characteristics of Respondents}

The major demographic variables included in this study were gender, age, academic status, field of specialization, teaching load and service years of the respondents. From the total number of respondents about 401(82.2\%) were males and the rest $87(17.8 \%)$ were females. This shows that majority of the respondents were male. The respondents age shows that about 229 (46.9\%) of the respondents were between 30-39 years old, which was age for majority of the respondents. Regarding academic qualification, $42(8.6 \%)$ of the respondents were diploma, $374(76.6 \%)$ were BEd/BA/BSc and 72 (14.7\%) were Med/MSc/MA. 
The respondents field of specialization shows that about $364(74.6 \%)$ were teaching, 109 (22.3\%) were EDPM/Educational leadership/School leadership and 15 (3.1\%) were other fields.

The teacher respondents teaching load also shows that about 48 (9.8\%) teachers teach less or equal to 10 periods per week, 158 (32.4\%) teachers teach 11-14 periods per week and $134(27.5 \%)$ teach greater or equal to 15 periods per week. The service years of the respondents shows that about 257 (52.7\%) were between 6 - 10 years of services while there were $91(18.6 \%)$ and 90 (18.4\%) respondents those served only between $11-15$ and $1-5$ years respectively.

In addition to this, a measure of the relative strength of an association between the demographic variables and practice of school autonomy was conducted by testing Cramer's V that indicated in the following Table 2.

The finding from the test of Cramer's $\mathrm{V}$ demonstrates that there was significant positive association/relationship between SA and the demographic data of the respondents.

\subsection{Areas of School Autonomy Exercised in School Leadership Practices}

The areas of SA those studied in this study were Personnel Management Autonomy (PMA), Financial Management Autonomy (FMA) and academic autonomy (AA). Accordingly, the descriptive and t-test analysis results of the data on the three areas were presented in Table 3 and Table 4 below.

\subsubsection{Personnel Management Autonomy}

According to the quantitative data analysis result, Table 3 below show that regarding PMA mean $(\mathrm{M})=3.18(66.6 \%), \mathrm{SD}=0.82$ of teachers and mean $(\mathrm{M})=$ $3.01(60.2 \%), \mathrm{SD}=0.79$ of education office experts positively agreed that their school was autonomous in personnel management. This show that in majority of the sample schools there PMA in areas such as planning for recruitment, professional skill development, professional ethics policy, hiring of staff, performance appraisal and students admission. But still there were about $33.4 \%$ of teachers and $39.8 \%$ of education office experts who said that the schools were failed to exercise PMA.

Table 2. Cramer's V test of strength of association between demographic variables and practice of school autonomy.

\begin{tabular}{cc}
\hline Variables & Cramer's V \\
\hline Gender & 0.45 \\
Age & 0.53 \\
Academic status & 0.71 \\
Field of specialization & 0.53 \\
Teaching load & 0.57 \\
Service year & 0.63 \\
\hline
\end{tabular}


Table 3. Descriptive statistics analysis of the major variables of the study

\begin{tabular}{cccccc}
\hline Types of variables and respondents & & N & Mean & SD & SEM \\
\hline PMA & Teachers & 341 & 3.181 & 0.821 & 0.044 \\
& Experts & 147 & 3.014 & 0.789 & 0.065 \\
FMA & Teachers & 341 & 2.998 & 0.77 & 0.042 \\
& Experts & 147 & 2.988 & 0.633 & 0.052 \\
AA & Teachers & 341 & 3.422 & 0.681 & 0.037 \\
& Experts & 147 & 3.468 & 0.625 & 0.051 \\
SAA & Teachers & 341 & 2.61 & 0.848 & 0.046 \\
& Experts & 147 & 2.524 & 0.79 & 0.065 \\
SA (sum of PMA, FMA and AA) & Teachers & 341 & 3.2 & 0.636 & 0.034 \\
& Experts & 147 & 3.157 & 0.582 & 0.048 \\
\hline
\end{tabular}

Key: $\mathrm{N}=$ Number of respondents $\mathrm{SD}=$ Standard deviation, $\mathrm{SEM}=$ Standard error of mean.

Table 4. Independent Samples t-test result.

\begin{tabular}{|c|c|c|c|c|c|c|c|c|c|c|}
\hline \multirow{3}{*}{ Variables } & & \multicolumn{4}{|c|}{$\begin{array}{c}\text { Levine's Test for } \\
\text { Equality of Variances }\end{array}$} & \multicolumn{5}{|c|}{ t-test for Equality of Means } \\
\hline & & \multirow{2}{*}{ F } & \multirow{2}{*}{ Sig. } & \multirow{2}{*}{ t-test } & \multirow{2}{*}{$\mathrm{Df}$} & \multirow{2}{*}{$\begin{array}{c}\text { Sig. } \\
\text { (2-tailed) }\end{array}$} & \multirow{2}{*}{$\begin{array}{l}\text { Mean } \\
\text { D/ce }\end{array}$} & \multirow{2}{*}{ SED } & \multicolumn{2}{|c|}{$95 \%$ CID } \\
\hline & & & & & & & & & Lower & Upper \\
\hline \multirow[t]{2}{*}{ PMA } & Equal variances assumed & 0.03 & 0.9 & 2.08 & 486 & 0.04 & 0.17 & 0.08 & 0.01 & 0.32 \\
\hline & Equal variances not assumed & & & 2.11 & 287 & 0.03 & 0.17 & 0.08 & 0.01 & 0.32 \\
\hline \multirow[t]{2}{*}{ FMA } & Equal variances assumed & 9.29 & 0.01 & 0.14 & 486 & 0.88 & 0.01 & 0.07 & -0.13 & 0.15 \\
\hline & Equal variances not assumed & & & 0.16 & 333 & 0.87 & 0.01 & 0.07 & -0.12 & 0.14 \\
\hline \multirow[t]{2}{*}{ AA } & Equal variances assumed & 1.18 & 0.3 & -0.7 & 486 & 0.48 & -0.05 & 0.06 & -0.17 & 0.08 \\
\hline & Equal variances not assumed & & & -0.7 & 299 & 0.46 & -0.05 & 0.06 & -0.17 & 0.08 \\
\hline
\end{tabular}

Independent samples t-test was also conducted to test the differences between the sample groups. Accordingly, as indicated in Table 4 above, the test was resulted in $\mathrm{t}(287)=2.11, \mathrm{p}=0.03$ that means there was a significant difference between the group concerning PMA. The difference was on items about interference by external authorities, providing professional skill development trainings, hiring and firing of staff members.

\subsubsection{Financial Management Autonomy}

According to the results displayed on Table 3 above mean $(\mathrm{M})=2.99(59.8 \%)$, $\mathrm{SD}=0.77$ of teachers and mean $(\mathrm{M})=2.99(59.8 \%), \mathrm{SD}=0.63$ of education office experts positively agreed that their school was autonomous in financial management area while about $40.2 \%$ of teachers and experts responded that the schools were not autonomous in financial management. Therefore, majority of the schools were autonomous in allocating budgets for activities, procurement, raise funds, managing budgets and develop school finance. 
Independent samples t-test indicated in Table 4 above, $\mathrm{t}(333)=0.16, \mathrm{p}=0.87$ that means there was no significant difference between the group concerning financial management autonomy.

\subsubsection{Academic Autonomy}

As can be seen from Table 3 above, mean $(M)=3.42(68.4 \%), S D=0.68$ of teachers and mean $(\mathrm{M})=3.47(69.4 \%), \mathrm{SD}=0.62 \mathrm{of}$ the education office experts positively agreed that their school was autonomous in academic area while about $31.6 \%$ and $30.6 \%$ of teachers and experts respectively responded that the schools were not autonomous in academic area. Accordingly, majority of the schools were practicing academic autonomy in continuous assessment, students' attendance, preparing examinations and deciding on students' pass mark, deciding on late comer students and discipline issues.

Independent samples t-test indicated in Table 4 above, $\mathrm{t}(299)=-0.73, \mathrm{p}=$ 0.46 that means there was no significant difference between the group concerning academic autonomy.

\subsection{Correlation Analysis Result}

\subsubsection{Linearity of the Relationship}

Based on the scatter plots above (Figures 1-4), there were a linear positive relationship between all the independent variables, that is PMA, FMA and AA, and

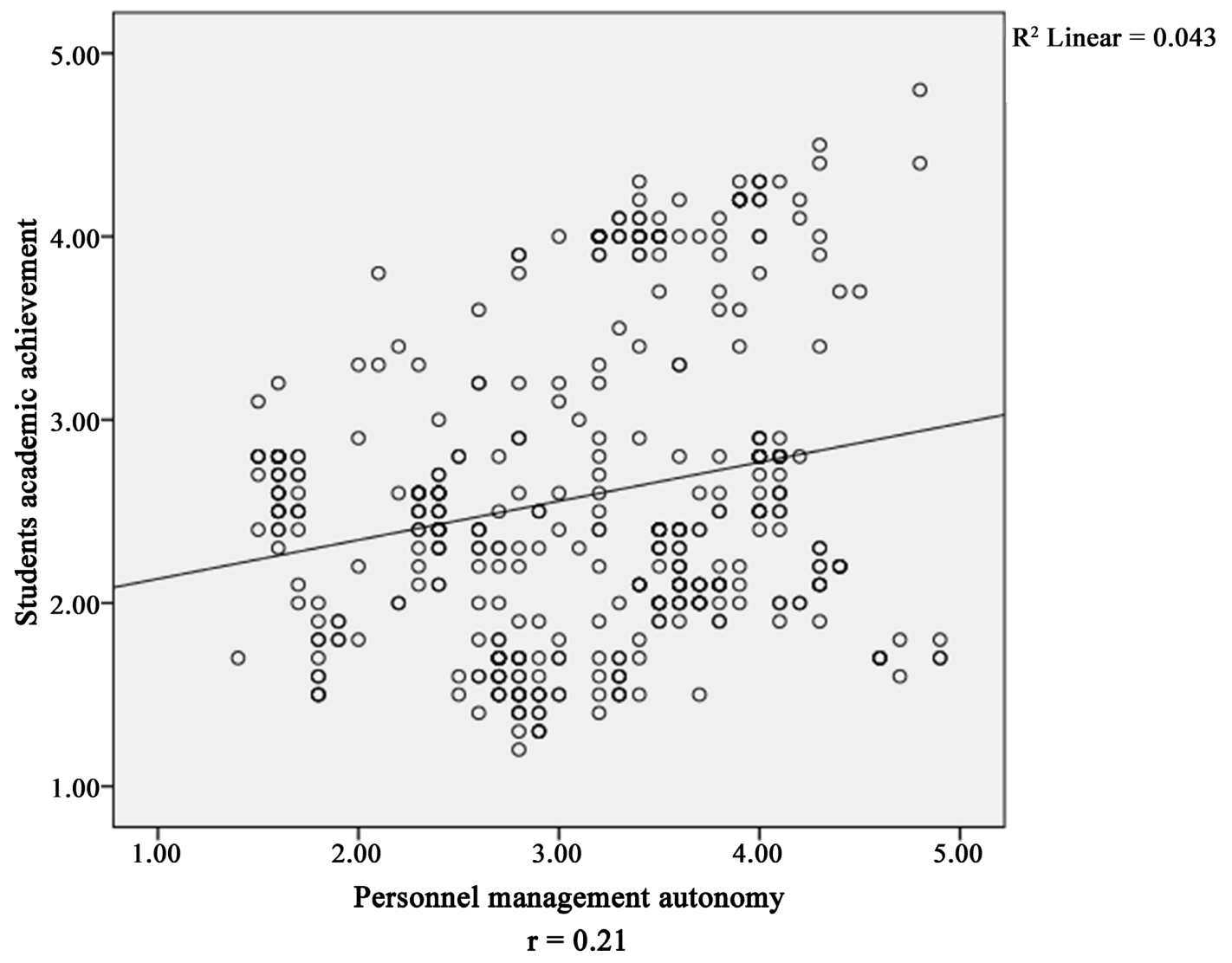

Figure 1. Scatter plot of PMA and SAA. 


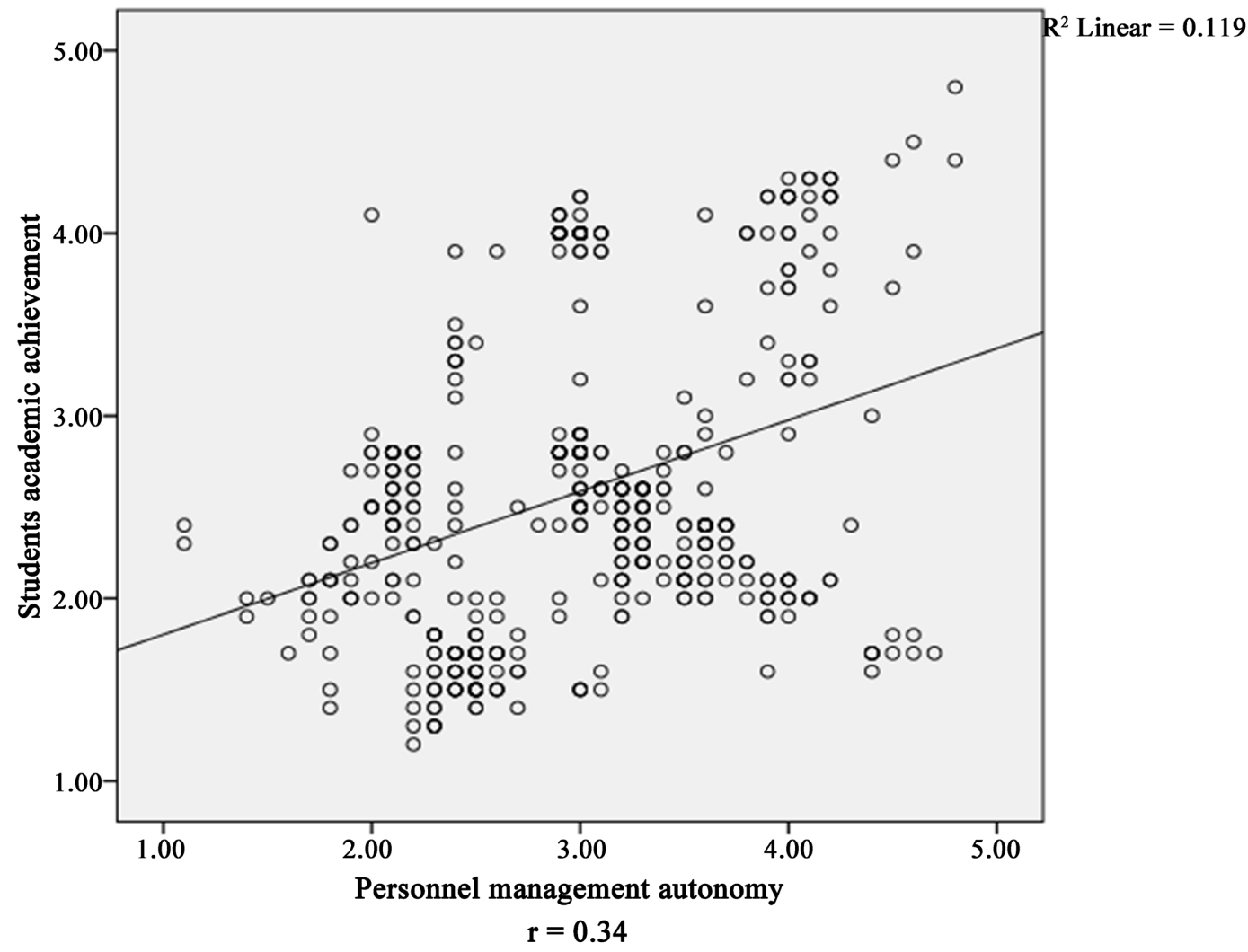

Figure 2. Scatter plot of FMA and SAA.

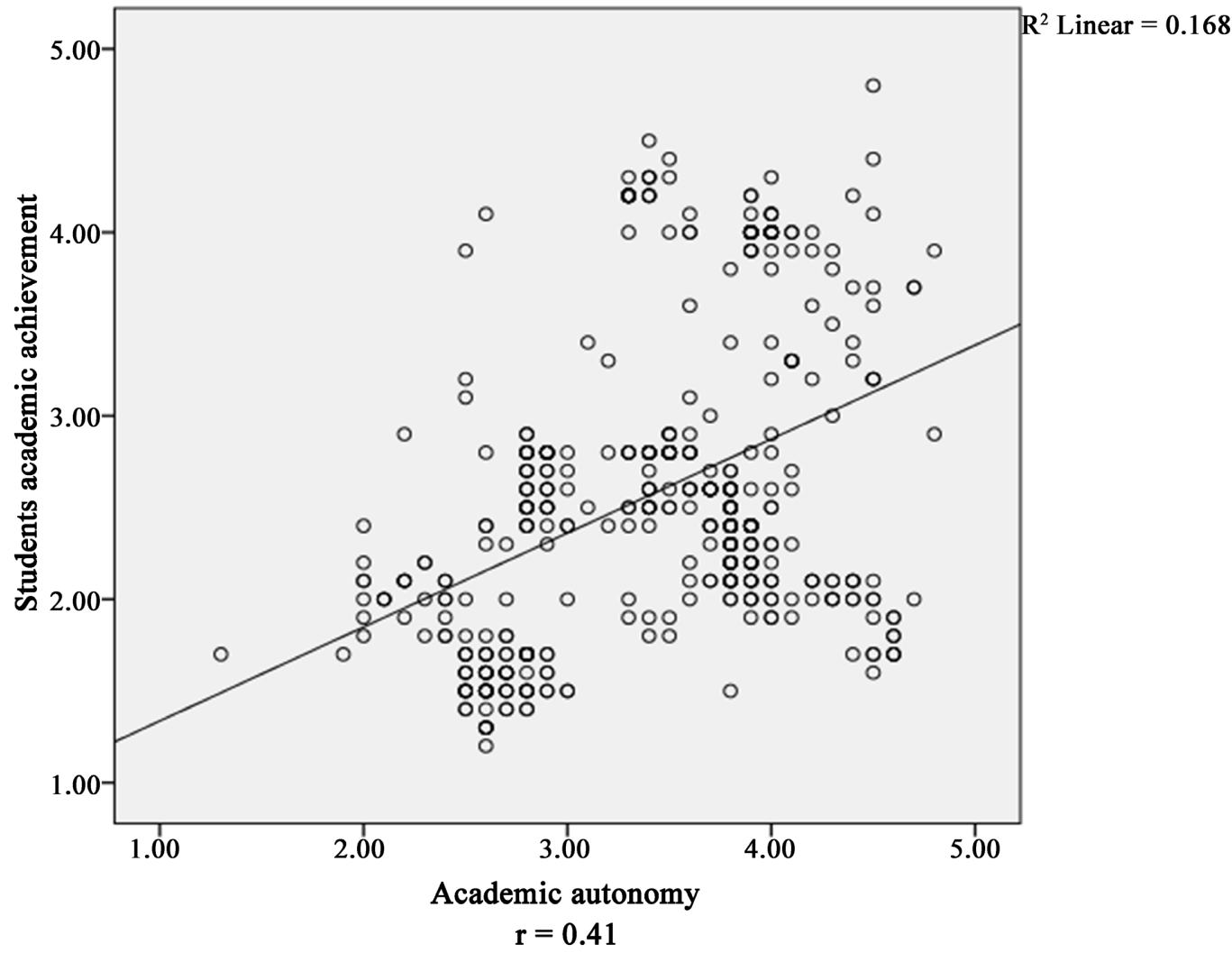

Figure 3. Scatter plot of AA and SAA. 


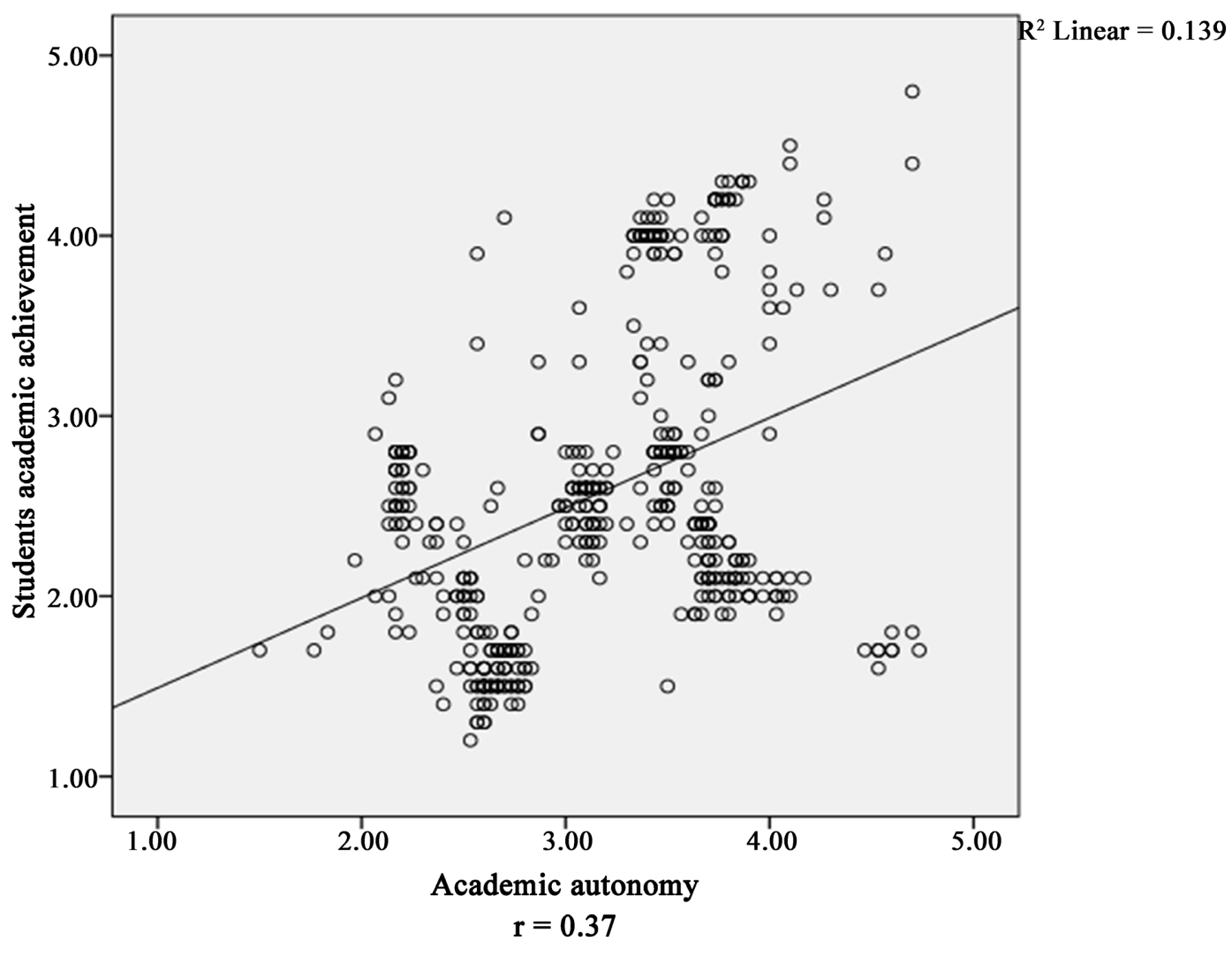

Figure 4. Scatter plot of SA and SAA.

the dependent variable SAA, or there was a linear positive relationship between SA and SAA. A number of literatures agree that the correlation coefficient (r) between 0.20 and 0.39 can be interpreted as weak correlation while $r$ between 0.40 and 0.59 can be interpreted as moderate correlation. Therefore, the relationships between "PMA and SAA" and "FMA and SAA" were weak positive relationship while the relationship between AA and SAA was moderate positive relationship, and overall the relationship between SA and SAA was weak positive relationship. Accordingly, the magnitude of the relationship between SA and SAA was weak positive magnitude that was $r=0.37$.

\subsubsection{Correlation Analysis Result of SA and SAA}

The correlation analysis result in Table 5 shows that the relationship between PMA and SAA is weak positive and highly significant $(r=0.21, p<0.001)$, that is, as the PMA of the schools increase, so does the SAA. Similarly, the relationship between FMA and SAA is weak positive and highly significant $(r=0.34, p<$ 0.001 ), that is, as the FMA of the schools increase, so does the SAA. Moreover, the relationship between AA and SAA is moderate positive and highly significant $(\mathrm{r}=0.41, p<0.001)$, that is, as the AA of the schools increase, so does the SAA. Generally, the relationship between SA and SAA is positive and highly significant $(\mathrm{r}=0.37, p<0.001)$. This shows that there is positive and highly significant relationship between SA and SAA, that is, the more the schools were autonomous the more increase in students' academic achievement. 
Table 5. Pearson Correlation between SA dimensions and SAA $(\mathrm{n}=488, P<0.05)$.

\begin{tabular}{ccc}
\hline & Variables & SAA \\
\hline PMA & Pearson Correlation & $0.21^{* *}$ \\
& Sig. (2-tailed) & 0.001 \\
FMA & Pearson Correlation & $0.34^{* *}$ \\
& Sig. (2-tailed) & 0.001 \\
AA & Pearson Correlation & $0.41^{* *}$ \\
& Sig. (2-tailed) & 0.001 \\
SA & Pearson Correlation & $0.37^{* *}$ \\
& Sig. (2-tailed) & 0.001 \\
\hline
\end{tabular}

The finding was consistent with SABER (2016) that reported there was positive relationship between SA (particularly PMA, FMA, AA) and SAA. Moreover, a study conducted in Kenya in randomly selected schools had yielded that there was significant positive relationship between SA and student test scores (Duflo, Dupas, \& Kremer, 2015). The conclusion made by OECD, that is, 'greater autonomy in decisions related to academic issues and resource allocation tend to be associated with better school performance' also agree with the finding of this study (OECD, 2011). Accordingly, the finding of this study was correspondent to some of the previous studies.

\subsubsection{Stepwise Multiple Regression Analysis Result of SA Dimensions and SAA}

This section of the data analysis discusses the magnitude of predicators (PMA, FMA and AA) on the outcome variable (SAA) using the stepwise multiple regression and the coefficients of each predicators and outcome variable.

The analysis result indicates all the three dimensions of school autonomy (PMA, FMA and AA) predict the SAA. AA result $(\mathrm{F} 1,486=97.8, p<0.001)$ shows it significantly predicts SAA and explained about $16.8 \%$ of the variance in SAA. Similarly, the result of FMA (F2, $485=4.67, p<0.03)$ indicates the significant relationship with SAA and it was explained about $17.2 \%$ of the variance in SAA. This shows, among the three dimensions, AA and FMA significantly explained the SAA while the PMA was excluded out of the model due to its weak power of prediction (see Table 6).

In the coefficient Table 7, examining of the Beta weights (standardized regression coefficients), it can also be seen that all the variables are significant predictors of the SAA $(p<0.05)$. The Beta weights compare the relative importance of each independent variable in standardized terms. Accordingly, the analysis result in Table 7 show that AA has more prediction power than FMA (beta = 0.33 and beta $=0.12)$ on SAA. Therefore, SA has power of predicting SAA, that is, it is considered to be giving more autonomy to schools and increase performance of the schools (Sholderer, 2017). Similarly, Varatharaj, Abdullah and Ismail (2015), found that SA improve the education system of schools that 
Table 6. Model summary of SA on SAA.

\begin{tabular}{|c|c|c|c|c|c|c|c|c|c|}
\hline & & & & del sur & ary & & & & \\
\hline \multirow[b]{2}{*}{ Model } & \multirow[b]{2}{*}{$\mathbf{R}$} & \multirow[b]{2}{*}{ R Square } & \multirow{2}{*}{$\begin{array}{l}\text { Adjusted } \\
\text { R Square }\end{array}$} & \multirow{2}{*}{$\begin{array}{l}\text { Std. Error } \\
\text { of the } \\
\text { Estimate }\end{array}$} & \multicolumn{5}{|c|}{ Change Statistics } \\
\hline & & & & & $\begin{array}{c}\text { R Square } \\
\text { Change }\end{array}$ & $\begin{array}{c}F \\
\text { Change }\end{array}$ & df1 & df2 & $\begin{array}{l}\text { Sig. F } \\
\text { Change }\end{array}$ \\
\hline 1 & $0.41^{\mathrm{a}}$ & 0.168 & 0.17 & 0.76 & 0.17 & 97.82 & 1 & 486 & 0.001 \\
\hline 2 & $0.42^{\mathrm{b}}$ & 0.175 & 0.17 & 0.76 & 0.01 & 4.67 & 1 & 485 & 0.03 \\
\hline
\end{tabular}

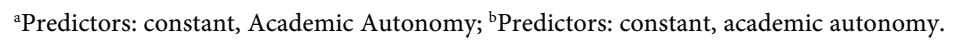

Table 7. The regression coefficients of SA variables on SAA.

\begin{tabular}{|c|c|c|c|c|c|c|}
\hline & \multirow{3}{*}{ Model } & \multicolumn{3}{|c|}{ Coefficients $^{\mathrm{a}}$} & \multirow{3}{*}{$t$} & \multirow{3}{*}{ Sig. } \\
\hline & & \multicolumn{2}{|c|}{ Unstandardized Coefficients } & \multirow{2}{*}{$\frac{\text { Standardized Coefficients }}{\text { Beta }}$} & & \\
\hline & & B & Std. Error & & & \\
\hline \multirow{2}{*}{1} & (Constant) & 0.82 & 0.18 & & 4.55 & 0.001 \\
\hline & AA & 0.51 & 0.05 & 0.41 & 9.89 & 0.001 \\
\hline \multirow{3}{*}{2} & (Constant) & 0.77 & 0.18 & & 4.21 & 0.001 \\
\hline & $\mathrm{AA}$ & 0.41 & 0.07 & 0.33 & 5.77 & 0.001 \\
\hline & FMA & 0.14 & 0.06 & 0.12 & 2.16 & 0.001 \\
\hline
\end{tabular}

${ }^{a}$ A dependent variable: students' academic achievement (SAA).

resulted in improvement of SAA.

Generally, the finding of this study was comparable with the findings of Fuchs and Woessmann (2007), that is, SAA is significantly better in schools that have PMA and FMA. In addition, the findings agree with argument of Nechyba (2003) that an increase in SA is likely to result in a rise in SAA. A study conducted by World Bank also concluded that SA in school resources management in general and particularly in financial management, personnel management and academic activities is considered to be desirable and a means to increase SAA (SABER, 2016).

The finding was also in contrary to the finding of PISA result of 2000-2009 and Hanushek, Link and Woessmann (2013) that concluded SA has negative influence on SAA in developing countries. Therefore, still the issue of relationship between SA and SAA is controversial and needs more studies by scholars or researchers.

\section{Conclusion}

It was universally acknowledged that an effective SA is a crucial tool for having a highly functioning school system. Previous studies have been considerably ambiguous and controversial regarding the relationship of SA with SAA in developing countries like Ethiopia. Empirical studies regarding this topic were quite limited for developing countries. Therefore, this study is an addition to the scarce study in the developing countries. 
Accordingly, the following conclusion was forwarded from the finding of the study. The SSs in the study area were exercising all the three dimensions of SA, that is, PMA, FMA and AA were practiced at moderate degree of autonomy in the schools. Moreover, SA practices in general and its three dimensions in particular have weak to moderate significant positive relationships with SAA. That is, schools with relatively better practices of SA may also have better scores in SAA. The overall conclusion drawn from the results of this study was that granting autonomy may be the best idea for the educational systems in the study area.

The Pearson correlation analysis resulted from the three dimensions of SA has a significant and positive relationship with SAA. That is, academic autonomy has a moderate positive and relationship with SAA. Similarly, there is a weak positive and significant relationship between PMA, FMA and SAA. Therefore, the magnitude of relationship between SA and SAA ranges from weak to moderate positive relationship, and the SA has good prediction power of SAA.

Generally, the finding of this study shows that there were practices of SA and it has significant positive relationship with SAA in the study area. That is the three variables (PMA, FMA and AA) used as a measure of SA seem to have significant positive influence on SAA of the SSs in the study area.

Moreover, the researcher recommended that SA policies are required to be formulated and implemented in the study area to increase SAA of the schools in the zone. The school leaders and teachers must give autonomy to exercise their roles and responsibilities that will result in better school performance. In addition, similar studies have to be conducted in the study area as well as in the country to answer the argument between researchers regarding the feasibility of SA and its influence on SAA.

\section{Acknowledgements}

I wish to gratefully acknowledge the people who have contributed ideas, assistances, and relevant support in the completion of this article. First and foremost, it is with deep respect I express my sincere gratitude to Associate Professor Ziyn Engdasew $(\mathrm{PhD})$. His expert advice and enormous encouragement has totally enhanced my capacity to complete this study. Thankfulness is also expressed to Associate Professor Garkebo Basha (PhD) and Feyera Dinsa (PhD) for their appropriate promptness in assisting me to gain a comprehensive knowledge of research methodology and greatly supported me to complete this study.

Likewise, I convey my gratitude to the Haramaya University for the full sponsorship provided to study my $\mathrm{PhD}$ degree and complete this study. This study would not have become a reality without the research fund provided by the University. In particular, I wish to thank Professor Mengistu Urge, the Academic Vice President of the University, who played a great role for providing me this greatest opportunity of joining $\mathrm{PhD}$ program.

Finally, I wish to extend my deepest appreciation to my wife, Genet Tesfaye, 
who constantly encouraged me in the process of completing this difficult task. To all those who directly and indirectly contributed to this study, I also offer many thanks and forever be grateful.

\section{Conflicts of Interest}

The authors declare no conflicts of interest regarding the publication of this paper.

\section{References}

Abdulkadiroglu, A., Angrist, J. D., Dynarski, S. M., Kane, T. J., \& Pathak, P. A. (2011). Accountability and Flexibility in Public Schools: Evidence from Boston's Charters and Pilots. Quarterly Journal of Economics, 126, 699-748.

https://doi.org/10.1093/qje/qjr017

Abebe, W. (2012). School Management and Decision Making in Ethiopian Government Schools: Evidence from the Young Lives Qualitative School Survey. Addis Ababa.

Arcia, G., Patrinos, H., Porta, E., \& Macdonald, K. (2011). SABER School Autonomy and Accountability Background Paper. Working Paper No. 94450, The World Bank.

Barrera, F., Fasih, T., \& Patrinos, H. (2009). Decentralized Decision Making in Schools. The Theory and Evidence on School-Based Management. The World Bank.

Bloom, N., Lemos, R., Sadun, R., \& Reenen, V. (2015). Does Management Matter in Schools? Economic Journal, 125, 647-674. https://doi.org/10.1111/ecoj.12267

Brauckmann, S., \& Schwarz, A. (2014). Autonomous Leadership and a Centralized School System: An Odd Couple? Empirical Insights from Cyprus. The International Journal of Educational Management, 28, 823-841. https://doi.org/10.1108/IJEM-08-2013-0124

Caldwell, B. (2005). The Structure and Funding of the School System: Achieving an Optimal Balance of Centralization and Decentralization in Education. Australian Economic Review, 38, 1-27. https://doi.org/10.1111/j.1467-8462.2005.00355.x

Cheusheva, S. (2021). How to Select Random Sample in Excel. https://www.ablebits.com/office-addins-blog/2018/01/31/excel-random-selection-rand om-sample

Cochran, W. G. (1977). Sampling Techniques (3rd ed.). John Wiley \& Sons.

Di Gropello, E. (2004). Educational Decentralization and Accountability Structure in Latin American and the Caribbean Region. International Handbook of School Effectiveness and Improvement, 17, 503-522. https://doi.org/10.1007/978-1-4020-5747-2 28

Di Gropello, E. (2006). A Comparative Analysis of School Based Management in Central America. World Bank Working Paper No. 72, The World Bank. https://doi.org/10.1596/978-0-8213-6525-0

Dobbie, W., \& Fryer (2011). Getting Beneath the Veil of Effective Schools: Evidence from New York City. Working Paper 17632, National Bureau of Economic Research. https://doi.org/10.3386/w17632

Duflo, E., Dupas, M., \& Kremer (2015). School Governance, Teacher Incentives, and Pupil-Teacher Ratios: Experimental Evidence from Kenyan Primary Schools. Journal of Public Economics, 123, 92-110. https://doi.org/10.1016/j.jpubeco.2014.11.008

Eskeland, G. S., \& Filmer, D. (2007). Autonomy, Participation, and Learning in Argentine Schools (Vol. 2766). World Bank Publications, The Determinants of German Students' Achievement in the PISA 2000-2009 Study.

http://papers.ssrn.com/sol3/papers.cfm?abstract id $=392040$ 
Ethiopian Academy of Sciences (2015). Annual Report of the Ethiopian Academy of Sciences 2014/2015. Addis Ababa.

Eurydice (2007). School Autonomy in Europe: Policies and Measures.

Fuchs, T., \& Woessmann, L. (2007). What Accounts for International Differences in Student Performance? A Re-Examination Using PISA Data. Empirical Economics, 32, 433-464. https://doi.org/10.1007/s00181-006-0087-0

Gay, L. R., Mills, G. E., \& Airasian, P. W. (2009). Educational Research: Competencies for Analysis and Applications (9th ed.). Prentice Hall.

Hanushek and Woessmann (2011). The Economics of International Differences in Educational Achievement. In E. A. Hanushek, S. Machin, \& L. Woessmann (Eds.), Handbook of the Economics of Education (Vol. 3, pp. 146-184). North Holland.

Hanushek, E. A., Link, S., \& Woessmann, L. (2013). Does School Autonomy Make Sense Everywhere? Panel Estimates from PISA. Journal of Development Economics, 104, 212232. https://doi.org/10.1016/j.jdeveco.2012.08.002

Manning, M., \& Munro, D. (2006). The Survey Researcher's SPSS Cookbook. Pearson Education.

Ministry of Education (MoE) (2017). Ethiopian Education Development Roadmap. Education Strategy Center (ESC).

MoE (1994). Directive for School Leadership and Financial Administration.

Naper, R. (2010). Teacher Hiring Practices and Educational Efficiency. Economics of Education Review, 29, 658-668. https://doi.org/10.1016/j.jdeveco.2012.08.002

Nechyba, T. (2003). What Can Be (And What Has Been) Learned from General Equilibrium Simulation Models of School Finance? National Tax Journal, 56, 387-414. https://doi.org/10.17310/ntj.2003.2.06

OECD (2011). School Autonomy and Accountability: Are They Related to Student Performance (p. 4)? PISA in Focus No. 9, OECD Publishing.

Organization for Economic Co-Operation and Development (OECD) (2014). Education at a Glance 2014: OECD Indicators. OECD Publishing.

Patrinos, H. A. (2011). School Based Management. In Making Schools Work: New Evidence on Accountability Reforms (pp. 87-140). World Bank.

https://doi.org/10.1596/9780821386798 CH03

SABER (2016). School Autonomy and Accountability. Education Global Practice. Smarter Education Systems for Brighter Futures. The World Bank Group.

Shibeshi, A. (2009). Overview of Education Research in Ethiopia Studies. Journal of Ethiopian Studies, 42, 141-174.

Sholderer, O. (2017). Making Education Work: School Autonomy and Performance. Department of Public Administration Leiden University. East European Quarterly, 45, 27 56. https://doi.org/10.2139/ssrn.3030700

Umansky, I. (2005). Central America: Education Strategies to Support Education for All. Invited Talk, Central American Regional UNESCO Education for All Conference, San Salvador, El Salvador, November 2005.

Varatharaj, R., Abdullah, A. G. K., \& Ismail, A. (2015). The Effect of Teacher Autonomy on Assessment Practices among Malaysian Cluster School Teachers. International Journal of Asian Social Science, 5, 31-36. https://doi.org/10.18488/journal.1/2015.5.1/1.1.31.36

Vegas, E., \& Petrow, J. (2008). Raising Student Learning in Latin America: The Challenge for the 21st Century. World Bank Publications. 


\section{https://doi.org/10.1596/978-0-8213-7082-7}

Woessmann, L. (2001). Why Students in Some Countries Do Better: International Evidence on the Importance of Education Policy. Education Matters, 1, 67-74.

Woessmann, L., Luedemann, E., Schutz, G., \& West, R. (2009). School Accountability, Autonomy, and Choice around the World. Edward Elgar.

World Bank (2007). What Is School Based Management System? The World Bank.

World Bank (2013). Secondary Education in Ethiopia. Supporting Growth and Transformation. The World Bank.

Yamane, T. (1967). Statistics, an Introductory Analysis (2nd ed.). Harper and Row. 


\section{Appendixes}

\section{HARAMAYA UNIVERSITY \\ COLLEGE OF EDUCATION AND BEHAVIORAL SCIENCES \\ DEPARTMENT OF EDUCATIONAL PLANNING AND MANAGEMENT \\ PhD PROGRM IN EDUCATIONAL LEADERSHIP AND POLICY STUDIES \\ QUESTIONNAIRES TO BE FILLED BY SECONDARY SCHOOL TEACHERS AND OFFICE EXPERTS}

Dear Respondents: I am a PhD student of Haramaya University, Ethiopia. I am carrying out a study on the topic: Relationship between School Autonomy and Students' Academic Achievement in Government Secondary Schools in East Hararghe Zone, Oromia Regional State, Ethiopia. Thus, the main purpose of this questionnaire is to collect relevant information to compliment this research work. I request for your co-operation by helping to answer the questionnaire as per the instructions at the beginning of each section. The success of this study directly depends upon your honest and genuine response to each question. You are requested to be as frank as possible when answering this questionnaire. Your responses will be highly respected and accorded the highest confidentiality.

Thank you very much in advance for your taking time to fill out this questionnaire!

Show your agreement to fill the questionnaire by answering the following question.

Would you fill this questionnaire voluntarily?

\section{Note:}

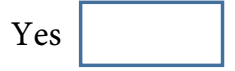

No

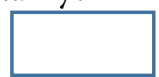

- You do not have to write your name.

- Your answer should represent your thinking or opinion.

- Feel free while filling out the questionnaire and reflect your views without any restrain

- Try to properly understand the statements before giving responses.

- Remember to go through all five pages of this questionnaire.

- In this questionnaire Autonomy means the authority of decision-making, or is the right/freedom of governing the school.

\section{Demographic Questions}

This part of questionnaire contains the personal information. Thus, please fill the necessary answer for each item properly by using a tick $(\sqrt{ })$ mark in the space provided.
1.1. Gender: - Male

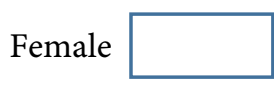
1.2. Age

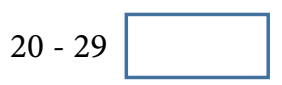
$30-39$
$40-49$

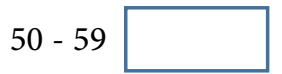
$\geq 60$

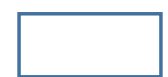

1.3. Your Academic qualification
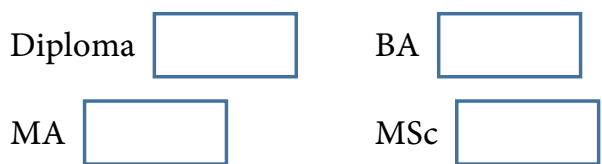

BSc

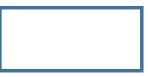

BEd

MA

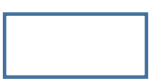

$\mathrm{MSc}$

Med

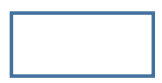

1.4. Field of your specialization

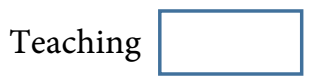

Applied science

Social science

Other 
1.5. Your teaching load per week (if you teach)

$\leq 10 \square+11-14 \square \quad 15-19 \square \geq 20 \square \square$

1.6. Your years of service as teacher
$1-5 \square$
$6-10$
$11-15$
$16-20$
$\geq 21$

1.7. Your years of service as school principal/vice principal (if you have been assigned)
$1-5 \square$
$6-10$
$11-15$
$16-20$
$\geq 21$

\section{Questions Related to School Autonomy and Students Academic Achievement}

\section{Part I: Perceptions Regarding School Autonomy}

How do you perceive the following statement? Please indicate your rating with a tick $(\sqrt{ })$ mark in the spaces provided against each item under the rating scales.

Note: $1=$ Not at all, $2=$ Occasionally, $3=$ Undecided, $4=$ Frequently, and $5=$ Always

\begin{tabular}{|c|c|c|c|c|c|c|}
\hline S/No. & Statements & 1 & 2 & 3 & 4 & 5 \\
\hline 1. & School autonomy leads to school improvement. & & & & & \\
\hline 2. & School autonomy creates higher participation of stakeholders to improve students' achievement. & & & & & \\
\hline 3. & School autonomy has positive impact on students' academic achievement. & & & & & \\
\hline 4. & School autonomy can motivate student to work effectively. & & & & & \\
\hline 5. & School autonomy can benefit students' parent. & & & & & \\
\hline 6. & School autonomy creates smooth relationship between teachers and students & & & & & \\
\hline 7. & School autonomy creates active teaching-learning in the classroom & & & & & \\
\hline 8. & School autonomy can result in better classroom management. & & & & & \\
\hline
\end{tabular}

\section{PART II: Personnel Management Autonomy}

The following statements are about autonomy/freedom of school leaders (principals/directors) in personnel management. Please indicate your rating with a tick $(\sqrt{ })$ mark in the spaces provided against each item under the rating scales.

Note: 1 = Strongly Disagree, $2=$ Disagree, $3=$ Undecided, $4=$ Agree, and $5=$ Strongly Agree

\begin{tabular}{|c|c|c|c|c|c|c|}
\hline S/No. & Statements & 1 & 2 & 3 & 4 & 5 \\
\hline 1. & Directors are empowered to plan for recruitment of staff. & & & & & \\
\hline 2. & Directors are free to implement teachers' professional ethics policy. & & & & & \\
\hline 3. & Directors are exposed to interference by external authorities. & & & & & \\
\hline 4. & Directors are free to provide any professional skill development trainings for staff. & & & & & \\
\hline 5. & Directors are empowered to make free decision on hiring of staff members. & & & & & \\
\hline 6. & Directors are empowered to make free decision on firing of staff members. & & & & & \\
\hline 7. & Directors are free decision-maker on performance appraisal of staff members. & & & & & \\
\hline 8. & Directors are free decision-makers regarding students admission.. & & & & & \\
\hline
\end{tabular}




\section{Part III: Financial Management Autonomy}

The following statements are related to the autonomy/freedom in financial management. Please indicate your rating with a tick $(\sqrt{ })$ mark in the spaces provided against each item under the rating scales.

Note: 1 = Strongly Disagree e, $2=$ Disagree, $3=$ Undecided, $4=$ Agree, and $5=$ Strongly Agree

\begin{tabular}{|c|c|c|c|c|c|c|}
\hline S/No. & Statements & 1 & 2 & 3 & 4 & 5 \\
\hline 1. & Directors are empowered to allocate the school's budgets for activities. & & & & & \\
\hline 2. & Directors are empowered for procurement of educational materials. & & & & & \\
\hline 3. & Directors are empowered to manage only operational budgets. & & & & & \\
\hline 4. & Directors are free to raise funds in addition to other budgets. & & & & & \\
\hline 5. & Directors are free to develop a budget aligned to staff needs. & & & & & \\
\hline 6. & Directors are empowered to decide on any expenses of the school's budget. & & & & & \\
\hline 7. & Teachers involve in budget planning through their representatives. & & & & & \\
\hline 8. & Teachers involve in decision-making regarding budget utilization. & & & & & \\
\hline
\end{tabular}

\section{Part IV: Academic Autonomy}

The following statements are about academic autonomy/freedom in the school. Please indicate your rating with a tick $(\sqrt{ })$ mark in the spaces provided against each item under the rating scales.

Note: $1=$ Not at all, $2=$ Occasionally, $3=$ Undecided, $4=$ Frequently, and $5=$ Always

\begin{tabular}{|c|c|c|c|c|c|c|}
\hline S/No. & Statements & 1 & 2 & 3 & 4 & 5 \\
\hline 1. & Teachers are empowered to practice continuous assessments. & & & & & \\
\hline 2. & Teachers are empowered to decide on students' class attendance. & & & & & \\
\hline 3. & Teachers are fully empowered to prepare examination questions. & & & & & \\
\hline 4. & Teachers freely decide on students who can sit for examination. & & & & & \\
\hline 5. & Teachers have full right not to let in late comer students to classroom. & & & & & \\
\hline 6. & Teachers participate on decisions regarding students' disciplinary issues. & & & & & \\
\hline 7. & Teachers have freedom on deciding students' pass/fail marks. & & & & & \\
\hline 8. & Teachers have freedom to express their feelings regarding academic decisions. & & & & & \\
\hline
\end{tabular}

\section{Part V: Constraining Factors of School Autonomy}

The followings are some of the problems/issues constraining the implementation of school autonomy/freedom. Please indicate your rating with a tick $(\sqrt{ })$ mark in the spaces provided against each item under the rating scales.

Note: $1=$ Strongly Disagree, $2=$ Disagree, $3=$ Undecided, $4=$ Agree, and $5=$ Strongly Agree

\begin{tabular}{|c|c|c|c|c|c|c|}
\hline S/No. & Statements & 1 & 2 & 3 & 4 & 5 \\
\hline 1. & Lack of guidelines/directives on the roles of principals. & & & & & \\
\hline 2. & Lack of knowledge on school autonomy/freedom. & & & & & \\
\hline 3. & Principals are inefficient in performing school activities. & & & & & \\
\hline 4. & Lack of school facilities & & & & & \\
\hline
\end{tabular}




\section{Continued}

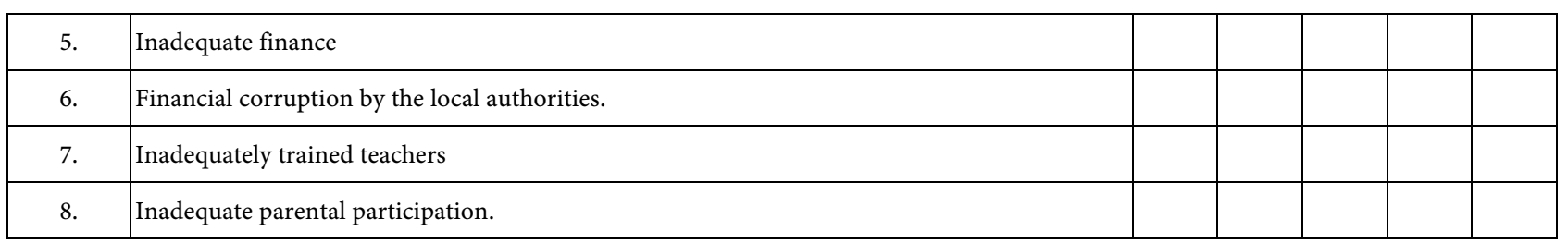

\section{Part VI: Students' Academic Achievement Improvement}

The following are indicators of improvement in students' academic achievement due to practice of school autonomy in the school. Please indicate your rating with a tick $(\sqrt{ })$ mark in the spaces provided against each item under the rating scales.

Note: 1 = Strongly Disagree, $2=$ Disagree, $3=$ Undecided, $4=$ Agree, and $5=$ Strongly Agree

\begin{tabular}{|c|c|c|c|c|c|c|}
\hline S/No. & Statements & 1 & 2 & 3 & 4 & 5 \\
\hline 1. & Students' behavior in the school is good. & & & & & \\
\hline 2. & Students of the school are punctual. & & & & & \\
\hline 3. & Most of the time there is high number of absentees. & & & & & \\
\hline 4. & There is low dropout rate in the school. & & & & & \\
\hline 5. & Students of the school have good motivation for learning. & & & & & \\
\hline 6. & Students are ready to stay in the school up to the end of school time. & & & & & \\
\hline 7. & Students of the school perform high in school-made examinations & & & & & \\
\hline 8. & Students of the school are able to perform high in national examinations & & & & & \\
\hline 9. & Students are active participant of teaching-learning process. & & & & & \\
\hline 10. & Students of the school have developed culture of independence on exam. & & & & & \\
\hline
\end{tabular}

Thank you so much for your kind cooperation! 